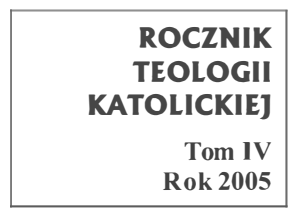

\title{
MATERIAŁY DO DZIEJÓW BUDOWY KATEDRY W BIAŁYMSTOKU
}

\author{
Oprac. ks. Tadeusz Krahel
}

W tym roku Kościół białostocki uroczyście obchodził 100-lecie poświęcenia bazyliki katedralnej Wniebowzięcia Najświętszej Maryi Panny. Z tej okazji wydano księgę jubileuszową Bazylika katedralna w Białymstoku ${ }^{1}$, w której zamieszczono szereg artykułów, dotyczacych dziejów tej szacownej świątyni. Warto zaznaczyć, że do początków XX w. Białystok miał tylko jeden mały kościół, pochodzący z początków XVII w. Tymczasem miasto na przestrzeni XIX w. stało się wielkim ośrodkiem przemysłowym, a parafia katolicka liczyła ok. 18000 katolików. Konieczna była budowa nowego kościoła. Władze carskie jednak nie pozwalały, argumentując tym, że póki jest jedna cerkiew w mieście, nie ma mowy o budowie drugiego kościoła. Zgodziły się tylko na powiększenie istniejącej świątyni. W 1900 r. ówczesny proboszcz i dziekan białostocki ks. Wilhelm Szwarc rozpoczą budowe „przybudówki” do starego kościoła. Projekt świątyni wykonał architekt Józef Dziekoński. Tempo prac było szybkie, skoro po pięciu latach prac kościół był już w takim stanie, iż można było go poświęcić i rozpocząc odprawianie nabożeństw. Poświęcenie miało miejsce w czasie wizytacji pasterskiej biskupa wileńskiego Edwarda Roppa w dniu 17.IX.1905 r., a dokonane zostało $\mathrm{z}$ upoważnienia biskupiego przez księdza prałata Jana Kurczewskiego. Wykańczanie kościoła trwało jeszcze przez wiele lat².

1 Białystok 2005, ss. 320, nlb. 32 foto.

2 Zob. K. A. Jabłoński, Katedra białostocka - jeden wiek w dziejach budowli, w: Bazylika katedralna w Białymstoku. Księga jubileuszowa z okazji 100-lecia poświęcenia kościoła Wniebowzięcia Najświętszej Maryi Panny w Białymstoku (1905 - 17 IX - 2005), pod red. T. Krahela, Białystok 2005, s. 23-84. 
Włączając się w jubileusz 100-lecia poświęcenia katedry, pragniemy udostępnić czytelnikom dwa bardzo ważne źródła, dotyczące budowy tejże świątyni. Znajdują się one w Archiwum Archidiecezjalnym w Białymstoku. Nie maja jeszcze sygnatur, gdyż Archiwum jest w stadium porządkowania. Należą do zespołu „Parafia Wniebowzięcia Najświętszej Maryi Panny w Białymstoku".

Pierwsze źródło nosi tytuł „Kościół katolicki w Białymstoku”. Jest to rękopis formatu $23,5 \mathrm{~cm} \times 37,8 \mathrm{~cm}$, w twardej oprawie, zawierajacy dziewięć zapisanych kart oraz trzy czyste. Na drugiej niezapisanej karcie znajduje się następujący wpis: „Christus vincit + Augustus Card. Hlond Primas Poloniae die 5 mensis septembris a. D. 1945". Kardynał Hlond, odwiedzając wygnanego z Wilna arcybiskupa metropolitę Romualda Jałbrzykowskiego gościł na plebanii parafii farnej i poproszono Go o wpis do tegoż pięknie oprawionego rękopisu.

Rękopis ten zawiera opis starań o budowę kościoła farnego, przebieg budowy, wykaz wydatków na ten cel, a także wyszczególnienie ważniejszych ofiarodawców i dobrodziejów. Jest to opis firmowany przez ks. dziekana Wilhelma Szwarca, który na końcu własnoręcznie się podpisał i podał swoje godności i ordery: „Ks. Wilhelm Szwarc Proboszcz i Dziekan Białostocki, Kanonik honorowy Katedry Wileńskiej i Kawaler Orderów Św. Stanisława III i II st. Św. Anny III i II st. Św. Włodzimierza IV i III stopnia”. Rękopis ten nie ma daty powstania, ale z wykazu wydatków można sądzić, że powstał najwcześniej w drugiej połowie 1914 r. Mamy tam bowiem zapis: „Odnowienie wewnatrz nowego kościoła w 1914 roku - 1450 [rubli]”. Natomiast data śmierci ks. Szwarca - dzień 29 III 1915 r. ${ }^{3}$ - wyznacza krańcową granicę powstania tego źródła.

Jest to bardzo cenne i wiarygodne źródło do dziejów budowy obecnej katedry białostockiej. Jedyne zastrzeżenia moga budzić, zamieszczone na poczatku opisu, dane historyczne dotyczące powstania pierwszego kościoła w Białymstoku oraz zagarnięcia go przez arian. Znajdujemy tu odbicie ówczesnej wiedzy historycznej o początkowych dziejach Kościoła katolickiego w Białymstoku. Dziś już wiemy, że pierwsza świątynia w Białymstoku została zbudowana nie w 1584 r., ale znacznie wcześniej; mają też historycy poważne wątpliwości, a nawet odrzucają możliwość zawładnięcia kościołem białostockim przez protestantów ${ }^{4}$.

Drugie publikowane tu źródło nie ma własnego tytułu. Na teczce, w której się je przechowuje, mamy tytuł, pochodzący od archiwisty: „Opis

3 T. Krahel, Ksiqdz Wilhelm Szwarc, w: Bazylika katedralna w Białymstoku, s. 85-92.

4 J. Wiśniewski, Poczqtki Białegostoku i okolicznego osadnictwa, w: Studia i materiały do dziejów miasta Białegostoku, t. 4, Białystok 1985, s. 26-27; J. Maroszek, Rewelacyjne odkrycie nieznanych najstarszych dokumentów do Białegostoku, „Białostocczyzna”, 1999, nr 1, s. 5-30; T. Krahel, Zarys dziejów parafii Wniebowzięcia Najświętszej Maryi Panny w Białymstoku, w: Bazylika katedralna w Białymstoku, s. 11-22. 
budowy kościoła farnego". Jest to rękopis formatu 22,8 x $36,8 \mathrm{~cm}$, składajacy się z dwóch kart. Zapisane są trzy strony. Tekst jest w kolumnach, zajmujacych pół stronicy. Druga połówka strony jest czysta. Jest to bardzo zwięzłe źródło, podajace informacje od dnia rozpoczęcia prac budowlanych w dniu 19 IV 1900 r. do dnia 28 X 1907 r. Choć rękopis ten jest krótki, to jednak jest bardzo cenny, gdyż w nim znajdujemy informacje, których nie mamy w innych materiałach, $\mathrm{np}$. datę dzienną rozpoczęcia prac przy wykopach pod fundamenty. Nie wiemy, kto był autorem tych zapisów.

W publikowanych materiałach zachowujemy ówczesny styl, uwspółcześniamy jedynie pisownię.

\section{Nr 1}

\section{Kościół katolicki w Białymstoku}

Pierwiastkowo w Białymstoku zbudowany był w 1584 r. Kościół drewniany, jakiś czas zawładnięty był przez heretyków (Arianów) ${ }^{5}$. Następnie Wielki Marszałek Wielkiego Księstwa Litewskiego Piotr Wiesiołowski, gorliwy katolik (jak niesie podanie) kazał ten Kościół spalić, a na tym miejscu z fundamentów z cegły palonej wybudował nowy w 1617 roku, co wskazuje wydobyta tablica przy rozebraniu części fundamentów starego Kościoła w dniu 20-go Maja 1902 r. z nadpisem: „Bogu Wszechmocnemu Najwyższemu na chwałę i cześć Bogarodzicy Dziewicy Maryi i wszystkich Świętych sławę. Kościół ten z drzewa przedtem zbudowany, teraz zaś z cegieł palonych od fundamentów wzniósł Piotr Wiesiołowski, Wielki Marszałek Wielkiego Księstwa Litewskiego 1617".

Po trzecim rozbiorze Polski w 1795 roku, 24-go Października m. Białystok przyłączono do Prus. Po traktacie zaś pokojowym w Tylży, zawartym w 1807 roku, Białystok począł należeć do Rosji i od 1808 do 1842 roku był miastem obwodowym, odtą jest miastem powiatowym Grodzieńskiej guberni.

Kościół Białostocki zbudowany był bardzo małych rozmiarów, lecz gdy z czasem ludność katolicka w Białymstoku i okolicach jego zwiększyła się i doszła do 7000, szczupłość egzystującego Kościoła dała się bardzo odczuwać. Przeto przed 1860 rokiem poczęto myśleć o budowie nowego Kościoła lub powiększeniu egzystującego, lecz nastały nieszczęsne niepokoje w kraju i wszelkie te szlachetne projekta zabiły. Dopiero w 1880 roku, gdy nauczyciel religii w Szlacheckim Instytucie Panien i Realnym Gimnazjum, ksiądz Wilhelm Szwarc mianowany został Proboszczem i Dziekanem Białostockim, myśl ta - budowy nowego Kościoła lub powiększenie egzystującego na nowo podjęto. W ciagu tego czasu ludność katolicka Białostockiej parafii

${ }^{5}$ Zob wyjaśnienia wstępne i przypis nr 4. 
wzrosła do kilkunastu tysięcy, przeto mały egzystujący Kościół ani dziesiątej części ludności pomieścić w sobie nie mógł.

Gwałtowna potrzeba dużego Kościoła w Białymstoku dotykalną była dla wszystkich. W tym celu ks. Szwarc udawał się do pojedynczych p.p. budowniczych, jak również spraszał do siebie na raz po kilku rozstrzygając tą sprawę, wskutek czego sporządzono kilka planów. Gdy zaś wskutek dodatnich niektórych warunków miasto Białystok zaczęło się podnosić, podjęto myśl, że przy wzroście miasta powiększy się i ludność katolicka i następnie choćby i duży jeden Kościół niedostatecznym będzie dla zwiększonej ludności, postanowiono budować nowy kościół na innym miejscu i uznano zamknięty w 1887 roku cmentarz grzebalny katolicki pod nazwą „Ś-go Rocha”.

Zaproszono pierwszorzędnego budowniczego z Warszawy Akademika p. Józefa Dziekońskiego, któremu poruczono sporządzenie odpowiednich planów i gdy takowe zostały sporządzone przez p. Dziekańskiego - udano się do odpowiednich władz z prośba o zatwierdzenie i pozwolenie budowy nowego Kościoła. Lecz władze odmówiły, znajdując obrane miejsce za nieodpowiednie.

Następnie obrano miejsce w innej części miasta na tak zwanych „Starych Bojarach", gdzie obszerny plac, należący do miasta, Zarząd miejski bez żadnej płaty na ten cel ofiarował, lecz władze kraju nie zgodziły się na budowę Kościoła i na tem miejscu.

Wówczas zbiorowo przez parafian uczynione zostało na Najwyższe Imię podanie z prośba pozwolenia budowy nowego Kościoła, wskutek czego Pan Minister Spraw Wewnętrznych 31-go Marca 1898 r. za Niego przez odpowiednie władze zawiadomił, że „prośba parafian Białostockiego Kościoła podana na Najwyższe Imię o pozwolenie budowy Drugiego Kościoła w Białymstoku uwzględnioną być nie może, dopokąd nie będzie drugiej prawosławnej świątyni w Białymstoku, lecz im się nie wzbrania starać się powiększyć, rozszerzyć lub przebudować egzystujacy Kościół”.

W Sierpniu miesiącu 1898 roku Biskup Wileński Stefan Zwierowicz odbywał kanoniczną wizytę Kościołów Białostockiego Dekanatu, rozpatrzywszy rzecz na miejscu w obecności niektórych parafian - polecił Dziekanowi Białostockiemu ks. Szwarcowi stanowczo przystapić do rozszerzenia egzystującego Kościoła. Jakoż natychmiast powtórnie udano się do budowniczego p. Dziekońskiego o sporządzeniu ku temu odpowiednich planów. Na rozszerzenie Kościoła Białostockiego plan i kosztorys sporządzone zostały przez p. Dziekońskiego w Kwietniu miesiacu 1899 roku, a przez Urząd Gubernialny Grodzieński zatwierdzone zostały 16 listopada 1899 roku za No 108 w summie 117.815 rb. 88 kop. Wskutek czego Wileński Rzymsko-Katolicki Konsystorz z datty 8-go Lutego 1900 r. za No 1114, na zasadzie prawa 5 punktu 124 artykułu obcych wyznań polecił Białostockiemu Dziekanowi rozszerzyć Białostocki Kościół środkami dobrowolnych ofiar składanych przez parafian.

Chlubnie znany ze znajomości budowniczej i sumiennego wykonania majster Białostocki Jan Albrecht wezwany został do prowadzenia funda- 
mentów pod nowy Kościół stosownie do wydawanych planów przez budowniczego p. Dziekońskiego.

Na zasadzie upełnomocnienia przez Wileńskiego Biskupa J.E. Stefana Aleksandra Zwierowicza z datty 9-go Maja 1900 r. za N. 1688, Dziekan i proboszcz Białostocki, Kanonik honorowy Katedry Wileńskiej Wilhelm Szwarc, 11-go Czerwca 1900 roku uroczyście poświęcił kamień węgielny.

Komitet budowlany na czele z ks. Dziekanem Szwarcem, przyjmując $\mathrm{w}$ uwagę trudności skomplikowane do wykonania robót połączenia starego Kościoła z nowym, sklepienia w całym Kościele i budowa wież, wezwał chlubnie rekomendowanego specjalistę budowy Kościołów p. Wacława Wędrowskiego z Warszawy, który 22 kwietnia 1902 r. rozpoczął dalsze prowadzenie budowy Kościoła.

Z rozporządzenia Biskupa Wileńskiego J. E. Barona Edwarda Roppa, Prałat Katedry Wileńskiej Ks. Jan Karczewski 17-go września 1905 r. uroczyście poświęcił i odtąd wprowadzone zostało nabożeństwo do nowo budującego się Kościoła.

Od dnia 20 Kwietnia 1900 r. do dnia 22 Kwietnia 1902 r. roboty mularskie i kamieniarskie prowadzone były gospodarczym sposobem przez wyżej wspomnianego p. Albrechta pod dozorem komitetu Kościelnego i dwóch techników od p. Dziekońskiego; za ten czas zrobiono fundamenta pod cały Kościół z kamienia polowego i z ciosanego kamienia cokół, a nad cokołem wyprowadzono ściany i filary z cegieł do wysokości 3-ch arszyn.

Od dnia 22 Kwietnia $1902 \mathrm{r}$. wszelkie roboty mularskie, cementowe i sztukatorskie prowadzone i wykonane były przez p. Wędrowskiego i jego podmajstrzego Franciszka Stryjeckiego i zakończone zostały 27-go Października 1907 roku. W tym że czasie został gruntownie odnowiony stary Kościółek jak wewnątrz tak i na zewnątrz, na nowo otynkowany, dach pokryty nową dachówką „Pustelnika”, drewniane części wieży wyreperowane i pokryte cynkową blachą, zrobiono nowych sześć żelaznych okien i na nowo oszklono, wewnątrz stary Kościółek został oddzielony od nowego murowana ścianą i zrobiono dwoje drzwi do przejścia; na górze nad sklepieniem ułożono drewniana podłogę jak w starym tak i w nowym Kościele.

Dom kościelny (była dobroczynność) gruntownie odrestaurowano i oddano do użytku kościelnego.

Nowy Kościół zbudowany z czerwonej cegły na kamiennym fundamencie i takim że cokole.

\section{Rozmiary Kościoła:}

Wysokość dwóch wież z krzyżami

Wysokość głównej nawy od posadzki

$102 \operatorname{arszyn}$

Wysokość dwóch bocznych naw od posadzki

33 arszyn

Długość kościoła na zewnątrz

17 arszyn 96 arszyn 
Szerokość w ramieniu krzyża

50 arszyn

Szerokość z bocznymi nawami

Krzyże na wieżach od kul do końca

Kule miedziane pozłacane na wieżach, średnica

37 arszyn

4 arszyn

1 arszyn

Wieża-sygnaturka od kipy dachu do końca krzyża

27 arszyn

Dach od belek do kipy

12 arszyn

\section{Ogólny rozchód na budowe Kościoła:}

1. Budowniczemu p. Dziekońskiemu i jego pomocnikom w przeciagu 8 lat $\mathrm{Rb} 6362,30 \mathrm{kop}$.

2. Kamieni do fundamentów, oprócz zwiezionych w dużej ilości na ofiarę przez parafian, dokupiono 10260 fur na sumę 8050,-

3. Rozbicie kamieni i ciosanie na cokół pod cały Kościół z węgłami i fazką, zapłacono p. Łajkowskiemu 1063,87

4. Cegła rozmaita używana do budowy Kościoła z cegielni p. Łyszczyńskiego z Markowszczyzny:

2.572.670 sztuk na sumę Rb:

21.000 sztuk od p. Kocha na sumę

32194,90 kop.

4.000 sztuk od p. Grancowa z Warszawy

256,20

10.000 sztuk od p. M. Corna

85,93

800 sztuk od p. Puchalskiego

ofiara

ofiara

2.608.470 sztuk - na ogólną sumę

32537,03

5. Zwózka cegły, oprócz zwiezienia przez parafian na ofiarę

- z cegielni p. Łyszczyńskiego

615,99

6. Kopanie dołów pod fundamenta, prócz ofiary od parafian

- kosztowało

7. Rozebranie części starego ogrodzenia

14,40

8. Wapna 57.811 1/2 pud. - na sumę

9288,63

9. Cementu 2.133 beczki - na sumę

8010,55

10. Mularskie roboty:

a) gospodarczym sposobem przy starym Kościele

$3.502,40$

b) gospodarczym sposobem przy nowym Kościele

$8.386,33$

c) p. Węgrowskiemu przy obliczeniu

$45.390,-57278,73$

11. Drzewny materiał razem z piłowaniem, do całej budowy, jako to: belki, krokwie, deski, sztandary i rusztowanie

12636,09

12. Budowa dachu i trzech wież przez majstra ciesielskiego p. K. Szulca

1200,60

13. Pokrycie dachu dachówką „Pustelnika” z Warszawy:

do nowego kościoła

do starego kościoła

$\mathrm{Rb}: 2811,60$

526,43

3338,03 
14. Blacha miedziana do 3-ch wież i na holkieli

5434,23

15. Pokrycie blachą 3-ch wiez, rynny i wszelka blacharska robota wykonana przez majstra z Warszawy p. Frankiewicza:
a) na nowym Kościele
$\mathrm{Rb}: 3944,17$
b) na starym Kościele
230.- 4174,17

16. Oszklenie Kościoła przez firmę „F. Białkowski i S-ka” w Warszawie:

a) $\mathrm{W}$ prezbiterium środkowe figuralne jedno okno

$\mathrm{Rb}: 1561$.

b) Dwa boczne w prezbiterium (szkło katedralne)

1338.-

c) 22 okna górnej kondygnacji (szkło zwyczajne zielone)

$1870 .-$

d) 6 okien w Krzyżu wraz z rozetami (szkło katedralne)

1108,50

e) 6 okien dolnej nawy (szkło katedralne)

1035.-

f) 2 okna dolne w wieży

198,90

g) 1 okno w kaplicy - ciemne dywanowe

182 .-

h) 1 okno boczne w kaplicy

122,75

i) 6 okien małych w przedsionkach

159 .-

j) 1 blat miedziany (herb m. Białegostoku)

$82 .-$

k) Rozeta duża nad chórem „Św. Cecylia”

600 .-

1) Szkło do wież górnej kondygnacji

565,29

m) Oszklenie małych okien

307,67

n) Oszklenie okien na dachu Kościoła

$8 .-$

o) Oszklenie starego Kościoła

46,92 Rb: 9185,03

17. Terrakotowa posadzka w nowym Kościele wykonana przez p. Piotrowskiego - zarządzającego biurem fabryki „Marywil” w Radomiu, na gotowym betonie $\mathrm{z}$ dodaniem cementu, wapna, piasku, wody, i t.p. obszarem 256,24 kw. sążni,

za ułożenie po obliczeniu

5776,80

Przed Kościołem podest górny i dolny

przy trotuarze

$937,72 ., 6714,52$

18. Dwanaście kamiennych stopni przed Kościołem, ułożonych na pełnym murze, 14 bieżących sążni po 10 rub. 1400 .-

19. Trzy piorunochrony, wypisane z Warszawy, kosztowały z przesyłka

Założenie przez p. Frankiewicza

100.- „376,42

20. Trzy płaskorzeźby na frontonie Kościoła nad trzema wejściami, przedstawiające Chrystusa Pana dźwigającego Krzyż i Zmartwychwstanie Pańskie - wykonane w zakładzie artystycznokościelnym „J. Szpetkowski i S-ka” w Warszawie Rb: 700.-

21. Fabryce żelaznej A. Wieczorka w Białymstoku, za wykonanie różnych robót z materiałem, jako-to: belki żelazne, ankry, lasze, krepowane klamry, obręcze żelazne, szruby, sztangi, okucie i pokrycie blachą drzwi zewnętrznych, żelazne sztachety $\mathrm{z}$ bramą $\mathrm{i}$ bocznymi furtkami

22. Blacha cynkowa i żelazna, beleczki żelazne, gwoździe $\mathrm{i}$ inne drobne materiały 
23. Cementowe i gipsowe ozdoby jak wewnattrz tak i na zewnątrz Kościoła

24. Żelazne szprosy do okien (z Warszawy od Prywesa)

25. Gips do roboty - 870 pudów

26. Dębowa posadzka w zakrystii

27. Cieśle przy rusztowaniu, robota bukszteli $\mathrm{i}$ inne ciesielskie roboty

28. Dwa stopnie z białego marmuru przy prezbiterium i przed kaplica

29. Woda do wapna i do roboty

30. Stolarskie roboty prowadzone były przez majstra

p. Stanisława Łuszczewskiego i wykonano:

troje zewnętrznych frontowych dużych drzwi, czworo drzwi zewnętrznych mniejszych i 32 drzwi wewnętrznych większych i mniejszych, balustrady, ławki, dwa konfesjonały w gotyckim stylu, do zakrystii: szafy, komody, mensy, do skarbca półki, podłogi, schody i dużo innych stolarskich robót na ogólną sumę

31. Malarskie roboty

32. Pokost, farby, klej, kwas solny do mycia ścian i t.p.

33. Przelanie dużego dzwonu w fabryce $\mathrm{p}$. Zwolińskiego w Warszawie

34. Przelanie dzwonu „sygnaturki”

35. Pozłocenie trzech kul na wieżach Kościoła

36. Blankiety wekslowe i \%\% Bankowi

37. Administracja i dozór

38. Różne drobne wydatki, gratyfikacje podmajstrzym i robotnikom, nafta, szwajcar, stróż i t.p.

39. Przebrukowanie ulicy przed Kościołem i ułożenie trotuaru

40. Dopłacono p. A. Szamańskiemu do nowych organów

41. Nowe murowane ogrodzenie Kościoła od ulicy

42. Rynna do ścieku wody (za Wielkim Ołtarzem)

43. Figura Matki Boskiej Niepokalanie Poczętej - do bocznej kaplicy

44. Ambona $z$ białego marmuru, części bronzowe, wykonana przez p. Lubowickiego z Warszawy

45. Ogrodzenie żelazne ambony $z$ drzwiczkami wykonane przez fabrykę „Gostyński i S-ka” w Warszawie

6. Bronzowanie ogrodzenia przy ambonie

47. Ustawienie elektromotoru do organów

48. Za wprowadzenie elektrycznego oświetlenia w nowym Kościele

49. Nowy Wielki Ołtarz drewniany, figuralny, dębowy pod wezwaniem „Wniebowzięcia Najświętszej Maryi Panny”, wykonany przez firmę 


\section{„J. Szpetkowski i S-ka” w Warszawie, przy udziale}

artysty-rzeźbiarza p. Wincentego Bogaczyka z Warszawy 28000.

50. Odnowienie wewnątrz nowego Kościoła w 1914 roku

1450.

Razem Rb 249.726, - 0 kop.

Prezesem Komitetu budowy Kościoła był ksiądz Kanonik Wilhelm Szwarc, wikariuszami przy Kościele Księża: Teodor Brazis i Wacław Grodzki; do składu Komitetu należeli p.p. Franciszek Malinowski, Antoni Wieczorek, Władysław Moniuszko, Józef Karpowicz, Józef Neryng, Hipolit Prago, Józef Rymiński, Rudolf Jakobi, Konstanty Łuszczewski, Konstanty Łowicki, Jan Kucharski, Aleksander Koch, Grzegorz Roleder, Romuald Lenczewski i Michał Borowski. Oprócz wymienionych obywateli miejskich, do składu komitetu należeli z 22 wsi Białostockiej parafii - 47 włościan deputowanych, którzy wraz ze swymi współbraćmi nieśli dużą pomoc jak ofiara pieniężną tak i natura przy budowie Kościoła, nie żałując pracy i trudu, nie zważając na wiek i stanowisko - przejęci jedną myślą wzniesienia Świątyni - składali swe ofiary, jako-to: zwiezienie kamieni do fundamentów, cegły, drzewa budowlanego, żwiru piasku, cementu, blachy, dachówki, terrakoty i wiele innych przedmiotów - wszystko to parafianie-włościanie zwozili na ofiarę.

Wielu z zamożniejszych obywateli hojne składali ofiary:

Zmarły w 1903 r. S.p. Jakób Sakowicz - obywatel i były Marszałek szlachty powiatu Białostockiego oprócz Rb. 3.000 - złożonych na budowę Kościoła i wielu innych ofiar - złożył Rb. 12.000 - na sprawienie nowych organów.

Zmarły w 1911 roku Ś.p. Konstanty Łuszczewski oprócz wielu innych ofiar złożył Rb. 1000 - na miedzianą blachę do pokrycia wieżyczki„sygnaturki” i dostarczył łat dachowych 3470 sążni na sumę Rb. 347,-

Zmarły w 1906 roku Ś.p. Antoni Wieczorek prócz większej kwoty pieniężnej - ofiarował 4 żelazne krzyże (3 szczytowe i 1 na sygnaturkę) na sumę Rb. 428,70 kop.

W roku 1906 - od parafian-pątników przywieziony został z Częstochowy obraz Matki Boskiej Częstochowskiej, do którego to obrazu pod przewodnictwem i staraniem Wikariusza miejscowego, Księdza Juljana Dudzińskiego, przy udziale miejscowych obywateli p.p. Aleksandra Zalewskiego i Józefa Chodorowskiego i wielu innych parafjan, droga specjalnych na ten cel składek, podług planu budowniczego p. Dziekońskiego z Warszawy, przez firmę „J. Szpetkowski i S-ka” w Warszawie, zbudowany został boczny ołtarz w stylu gotyckim z masy mozaikowej w sumie Rb. 8.000,- Do Ołtarza tego ofiarowano przez tych-że parafian-pątników 12 lichtarzy srebrnych, duży bronzowy żyrandol na 54 świece w cenie $\mathrm{Rb}$. 800 , bogaty baldachim, 4 halabardy. Jednocześnie do obrazu Matki Boskiej Częstochowskiej ofiarowaną została od małżonków Marcelego i Ewy Ramolów - zasłona 
z wyobrażeniem w malowidle „Przemienienia Pańskiego”. Poświęcenie ołtarza odbyło się w dniu 3 Maja 1908 r. przez miejscowego Ks. Kanonika W. Szwarca, w obecności Ks. Kanonika Jasieńskiego z Wilna, Ks. Juljana Dudzińskiego i innych księży i parafian.

Pracownicy stacji „Starosielce” wykonali na ofiarę z własnego materiału dębowy boczny ołtarz w stylu Gotyckim pod wezwaniem „Św. Antoniego i Św. Kazimierza”, obraz zaś przedstawiajacy Św. Antoniego, wykonany przez p. Kazimierza Stabrowskiego, w cenie Rb. 500 - ofiarował obywatel ziemski p. Józef Karpowicz.

Majster murarski p. Wacław Wędrowski z Warszawy, ofiarował do naszego Kościoła żelazną ręcznej roboty małą sygnaturkę w stylu gotyckim, wartości przeszło 300 rubli i takową zawieszono w prezbiterium - przy zakrystii.

Obywatel miejski p. Jan Kucharski zbudował na ofiarę piec w zakrystyi z kafli bronzowych wyrobu własnej fabryki w cenie 200 rubli.

Pracownicy niektórych fabryk m. Białegostoku ofiarowali duży bronzowy żyrandol w cenie 1.400 rub., ubrany ozdobnie kryształami i zastosowany do elektrycznego oświetlenia.

Obywatelka miejska, ś.p. Paulina Turczyńska ofiarowała bronzowy żyrandol w stylu gotyckim, w cenie 1.000 rub. i takowy zawieszony w prezbiterium.

Cech Białostockich stolarzy i zdunów ofiarował bronzowy żyrandol w cenie 333 rubli.

Obywatel miejski p. Stanisław Łuszczewski i p. Słowiński, jako wykonawca, wspólnie ofiarowali żyrandol z jelenich rogów w cenie 300 rubli, na 24 świece zastosowany do elektrycznego oświetlenia.

Parafjanin ze wsi Bagnówka - Jan Sosnowski ofiarował bronzowy lampierz przed Wielki Ołtarz.

Miejscowe panie-parafianki ofiarowały do Wielkiego Ołtarza 12 lichtarzy srebrnych w cenie przeszło 350 rubli.

Obywatelka miejska p. Marja Klimowicz ofiarowała dwie kamienne figury „Sw. Piotra i Św. Pawła” w cenie 300 rub. i takowe ustawiono przed frontem Kościoła.

Od parafian-pątników z pielgrzymki Częstochowskiej ofiarowano trzy figury Chrystusa Pana na Krzyzu, dwie figury umieszczono w kruchcie Kościoła nad kropielnicami, a jedną na filarze naprzeciw ambony.

Parafjanie prócz składek pieniężnych ofiarowali do nowego Kościoła 36 rozmaitych choragwi, tarcze, sześć feretronów i dużo innych drobnych untysylii kościelnych.

Ks. Wilhelm Szwarc

Proboszcz i Dziekan Białostocki Kanonik honorowy katedry Wileńskiej i Kawaler Orderów Ś. Stanisława III i II st. Ś. Anny III i II st. Ś. Włodzimierza IV i III stopnia 
[Na stronie trzeciej nieliczbowanej znajduje się następujący wpis:]

\author{
Christus vincit \\ + Augustus Card. Hlond \\ Primas Poloniae
}

die 5 mensis septembris a. D. 1945

\title{
Nr 2
}

\section{Opis budowy kościoła farnego}

Do pierwszych robót przystapiono w dniu 19 września 1900 roku przy 7 robotnikach wynajętych i kilkunastu parafian na ofiarę - zaczęto kopać doły na fundamenta i kupować kamieni.

Tego że dnia rozpoczął swa działalność tak zwany komitet budowlany składający się z obywateli miejskich w liczbie 14 jak również i z każdej wsi wybrano po dwóch włościan na czele z ks. Dziekanem Szwarcem i postanowili fundamenta pod nowy kościół wykonać gospodarczym sposobem.

$\mathrm{Z}$ miejscowych członkiem komitetu wybrany został p. Michał Borowski jako prowadzacy gospodarczą część przy budowie kościoła, a reszta członków do kontroli codziennej robotnika i dostawy materiałów po jednym każdego dnia.

Z dniem 1 Czerwca 1900 roku był zaangażowany jako nadzorca do wykonania fundamentów p. Jan Albrecht, który przy pomocy miejscowych roboczych sił i parafian na ochotnika - wykonał fundamenta pod cały nowo budujący się kościół, na nim ustawił z ciosanego kamienia cokół; z cegieł jak wewnątrz tak i na zewnątrz wyprowadzono ściany i filary do wysokości 3 arszyn i tam się zakończyły w dniu 15 listopada 1901 roku roboty prowadzone przez p. Albrechta.

Wyżej wspomniany komitet na czele z ks. Dziekanem Szwarcem - obsądzajac kwestię co do dalszej budowy kościoła z wiosna 1902 roku i mając na widoku przyszłość wykonania robót dosyć trudną i skomplikowana jako to: połaczenie starego kościoła z nowym, sklepienia w całym kościele i budowa dwóch wież - komitet przyszedł do wniosku, że konieczność wymaga prowadzenie robót oddać jednej kompetentnej osobie - ogólnie lub też od kwadratowego arszyna.

Po wielu debatach trzeba było sięgać rady u budowniczego p. Dziekońskiego i innych.

Jednocześnie był zarekomendowany jako specjalista budowy kościołów p. Wacław Wędrowski z Warszawy, który w dniu 30 grudnia 1901 r. podpisał umowę i rozpoczął roboty 22 kwietnia 1902 roku. 
Zakończenie robot mularskich przez p. Wędrowskiego nastąpiło 1 Lipca 1906 roku.

$\mathrm{Z}$ frontu nowego kościoła zrobiono nowe ogrodzenie murem i żelazne sztachety z bramą i bocznymi furtkami, gruntownie odnowiony stary kościółek jak wewnątrz tak i na zewnątrz; roboty były prowadzone gospodarczym sposobem od dnia 3 Maja do 28 Października 1907 roku. 